\title{
The 24-hour retirement rule for NHS dentists
}

\author{
By Sarah Lyons, ${ }^{1}$ Wesleyan Financial Services Consultant
}

If you're a dentist with an NHS pension, the 24-hour retirement rule allows you to access your benefits and return to work after retiring and downing tools for 24 hours.

You might sometimes have heard this referred to as 'retire and return' - as you retire for 24 hours before returning to work.

It can be an attractive option if you're looking to gradually ease into retirement but don't want a drop in income; however, your working hours may be limited to 16 hours a week for the first month depending on which part of the scheme you receive benefits from. It could also help you to pay for your children's university fees or simply fund the kind of lifestyle you want to have while working fewer hours.

Some people also use 24-hour retirement as a way to avoid the extra taxes and costs associated with reaching your lifetime allowance.

\section{The two parts of the 24-hour} retirement rule

However, there are two important parts to the rule that you must stick to:

- You have to physically give up your NHS contract for at least 24 hours. Many people do this over a weekend, so they effectively retire on Friday and go back on Monday

- You can't carry out more than 16 hours of work each week for the month after you retire (although this rule has currently been suspended due to COVID-19).

The name of the rule refers to how long you have to give up your contract for, not how long it takes to complete the process that allows you to take 24-hour retirement.

It can take months to put everything in place and ensure you're compliant with everything that is required by your NHS contract, the CQC and the Department of Health.

This means that it's worth thinking about as early as possible to make sure you can trigger it at the right time for you.

\section{Considerations for sole practitioners and partners}

When instigating 24-hour retirement, there are different considerations depending on whether you're a sole practitioner or a partner.

As a sole trader, once you notify the NHS that you want to retire, they will effectively terminate your contract and there is no legal requirement for them to reinstate it.

To mitigate the risk of losing your contract, you can consider entering into a temporary partnership with another dentist that you trust. After you have retired for 24 hours and returned to work, the contract can be switched from the temporary partnership back to just your name.

You will also need to register this new partnership with the CQC, especially if it will last longer than the 24 hours, and this would need to be complete before any changes were made to your NHS contract.

As a partner, the process is less complex. You can simply temporarily retire from your partnership without the threat of the NHS terminating the practice's contract.

However, you may still want to put measures in place or a written agreement to ensure you can return to the partnership and go back to work once the 24 hours are up.

\section{Start planning early}

Depending on your individual circumstances and plans for the future, there can be good reasons to consider 24-hour retirement.

There's also a lot to think about to make sure you abide by the rules, have the right agreements in place and protect yourself and your future.

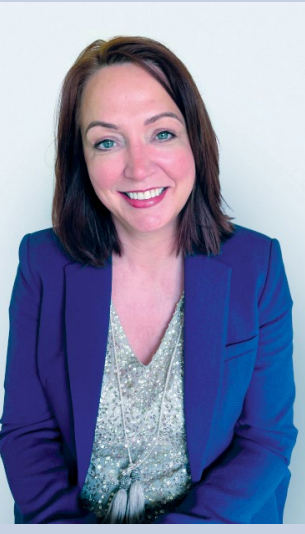

As a lengthy process, it's worth talking to someone who can help to talk through the options as early as possible.

If you'd like to discuss what 24-hour retirement would mean for you with a Wesleyan Financial Services Consultant who understands your circumstances as a dentist, visit www.wesleyan.co.uk/dental.

Alternatively, you can call us on: 0800316 3784, 9 am to $5 \mathrm{pm}$, Monday to Friday.

Advice is provided by Wesleyan Financial Services Ltd.

'WESLEYAN' is a trading name of the Wesleyan Group of companies.

Wesleyan Financial Services Ltd (Registered in England and Wales No. 1651212) is authorised and regulated by the Financial Conduct Authority and is wholly owned by Wesleyan Assurance Society. Wesleyan Assurance Society is authorised by the Prudential Regulation Authority and regulated by the Financial Conduct Authority and the Prudential Regulation Authority. Incorporated in England and Wales by Private Act of Parliament (No. ZC145). Registered Office: Colmore Circus, Birmingham B4 6AR. Telephone: 0345351 2352. Fax: 0121200 2971. Calls may be recorded to help us provide, monitor and improve our services to you. 